\title{
FH535 inhibits the proliferation of HepG2 cells via downregulation of the Wnt/ $\beta$-catenin signaling pathway
}

\author{
JING LIU ${ }^{1}$, GUANGBING LI² ${ }^{2}$ DEJIE LIU ${ }^{3}$ and JUN LIU ${ }^{2}$ \\ ${ }^{1}$ Department of Ophthalmology, The Second Hospital of Shandong University, Jinan, Shandong 250033; \\ ${ }^{2}$ Department of Liver Transplantation and Hepatobiliary Surgery, Provincial Hospital Affiliated to Shandong University, \\ Jinan, Shandong 250021; ${ }^{3}$ Department of Anesthesiology, Qilu Hospital Affiliated to Shandong University, \\ Jinan, Shandong 250012, P.R. China
}

Received September 12, 2013; Accepted January 23, 2014

DOI: $10.3892 / \mathrm{mmr} .2014 .1928$

\begin{abstract}
Hepatocellular carcinoma (HCC) is a primary cancer of the liver. Target therapy may improve prognosis of HCC. In the present study, we evaluated the inhibition of the $\mathrm{Wnt} / \beta$-catenin pathway as a potential therapeutic approach. HepG2 cells were treated with the $\beta$-catenin inhibitor FH535. $\beta$-catenin protein expression was semi-quantitatively assessed using western blot analysis. Cell proliferation was examined with a 3-(4,5-dimethyl-2-yl)-5-(3-carboxymethoxyphenyl)-2-( 4-sulfophenyl)-2H-tetrazolium salt (MTS) assay. The mRNA expression of nitric oxide synthase (iNOS) was detected by reverse transcription polymerase chain reaction. The Griess assay was used to determine nitric oxide (NO) concentration. FH535 inhibited the proliferation of HepG2 cells and decreased $\beta$-catenin protein expression. mRNA expression of $i N O S$, a target gene of the Wnt $/ \beta$-catenin pathway, was decreased in FH535-treated HepG2 cells compared to the control group. NO production was also reduced by FH535. In conclusion, the $\beta$-catenin inhibitor FH535 may inhibit HCC cell proliferation via downregulation of the Wnt/ $\beta$-catenin pathway. Thus, targeting this pathway may be useful in HCC therapy.
\end{abstract}

\section{Introduction}

Hepatocellular carcinoma (HCC) is a primary cancer of the liver that is predominant in developing countries, with almost 600,000 deaths per year worldwide $(1,2)$. HCC normally develops as a consequence of liver disease and is most often associated with cirrhosis (3). Surgical resection and liver transplantation are currently the best curative options to treat

Correspondence to: Professor Jun Liu, Department of Liver Transplantation and Hepatobiliary Surgery, Provincial Hospital Affiliated to Shandong University, 324 Jingwu Road, Jinan, Shandong 250021, P.R. China

E-mail: dr_liujun@hotmail.com

Key words: FH535, Wnt/ $\beta$-catenin pathway, induced nitric oxide synthase, nitric oxide liver cancer (4). However, recurrence or metastasis is common in patients who have had a resection, and the survival rate at 5 years post-operation is $30-40 \%$ (5). One of the challenges in modern hepatology is to improve the prognosis of HCC. A few adjuvant therapies have been relatively effective for a number of treatment-naïve or relapsing patients. These therapies include transcatheter arterial chemoembolization, radiofrequency ablation, selective internal radiation therapy and high-intensity focused ultrasound and targeted therapy, and are commonly combined in the clinic $(6,7)$.

The Wnt signaling pathway, originally identified in Drosophila melanogaster, is a highly conserved pathway involved in homeostasis, cell proliferation, differentiation, motility, and apoptosis (8). It is deregulated in a number of cancer types, including HCC (9). In most reported cases, Wnt signaling is activated either by the inactivation of the tumor suppressor gene adenomatous polyposis coli or the mutation of the proto-oncogene $\beta$-catenin. This pathway is also involved in $\mathrm{HCC}$ arising from $\mathrm{HBV} / \mathrm{HCV}$ infections and alcoholic liver cirrhosis (10). Upregulation of the Wnt receptor frizzled-7 and dephosphorylation of $\beta$-catenin is frequently observed in HCC. Therefore, targeted inactivation of Wnt pathway may be an effective therapeutic approach for cancer. FH535 is a small molecule that can inhibit $\beta$-catenin (11).

Nitric oxide (NO) is a diatomic free radical molecule. It is synthesized by the nitric oxide synthase (NOS) (12). There are three isoforms of NOS, the endothelial (eNOS), the neuronal (nNOS) and the inducible NOS (iNOS). A recent study has shown strong in situ co-expression of iNOS and eNOS in ductal carcinomas (13). This study shed light on the role of NO in tumorigenesis. Du et al showed that iNOS is regulated by the Wnt pathway in cancer cells (14).

In the present study, we investigated the effect of FH535 on the proliferation of HepG 2 cells. The results from our study showed that the FH535 inhibitor downregulates the expression of $\beta$-catenin, thereby reducing the production of NO. Reduced NO levels may underlie reduced proliferation of HepG2 cells.

\section{Materials and methods}

Cell culture. The human hepatocellular carcinoma (hepatoma) cell line HepG2 was maintained in Dulbecco's modified 
Eagle's medium (DMEM) supplemented with $10 \%$ fetal bovine serum (FBS), $100 \mu \mathrm{g} / \mathrm{ml}$ penicillin and $100 \mu \mathrm{g} / \mathrm{ml}$ streptomycin. All media and supplements were purchased from Invitrogen (Carlsbad, CA, USA). Cells were maintained at $37^{\circ} \mathrm{C}$ in a humidified atmosphere with $5 \% \mathrm{CO}_{2}$.

Protein extraction and immunoblotting. HepG2 cells were seeded in 6-well plates at 50\% confluency and incubated at $37^{\circ} \mathrm{C}$ overnight. The cells were then treated with phosphate-buffered saline (PBS) or with different concentrations $(2,10$ or $20 \mu \mathrm{g} / \mathrm{ml}$ ) of HPLC-purified FH535 (Sigma-Aldrich, St. Louis, MO, USA) for $48 \mathrm{~h}$. Cell monolayers were washed twice with PBS and then lysed in RIPA extraction buffer (PBS, $0.1 \%$ sodium dodecyl sulfate, $0.5 \%$ sodium deoxycholate, $10 \mu \mathrm{g} / \mathrm{ml}$ phenylmethylsulfonyl fluoride; Millipore, Bedford, MA, USA). Equal amounts of protein $(20 \mu \mathrm{g})$ were resolved on a sodium dodecyl sulfate-polyacrylamide gel (SDS-PAGE) and western blot analyses were performed using the primary antibodies targeting $\beta$-catenin (1:500, cat. no. SC-7963; Santa Cruz Biotechnology, Inc., Santa Cruz, CA, USA) and horseradish peroxidase (HRP)- $\beta$-actin (1:10,000, cat. no. A3854; Sigma-Aldrich). Secondary antibodies (anti-mouse, cat. no. SC-2005 and anti-rabbit, cat. no. SC-2004) conjugated with HRP were purchased from Santa Cruz Biotechnology, Inc.

Cell viability assay. HepG2 cells were seeded in 96-well plates at a density of $3 \times 10^{3}$ cells/well and incubated overnight at $37^{\circ} \mathrm{C}$ prior to the addition of a range of $\mathrm{FH} 535$ concentrations $(1.25-20 \mu \mathrm{g} / \mathrm{ml})$. The control HepG2 cells were treated with dimethylsulfoxide (DMSO). Cells were further incubated at $37^{\circ} \mathrm{C}$ in an incubator with a humidified atmosphere and $5 \% \mathrm{CO}_{2}$ for $72 \mathrm{~h}$ before cell viability was assessed using the CellTiter-Glo ${ }^{\circledR}$ Luminescent Cell Viability assay (Promega, Madison, WI, USA) according to the manufacturer's instructions. Three independent experiments were performed, each in triplicate.

Cell proliferation assay. Hepatoma cells were seeded in 96-well plates at $3 \times 10^{3}$ cells/well, maintained overnight at $37^{\circ} \mathrm{C}$, and incubated with $\mathrm{FH} 535$ at concentrations ranging from 0 to $100 \mu \mathrm{M}$. After incubation for $72 \mathrm{~h}$, cell proliferation was monitored using the CellTiter $96^{\circledR}$ AQueous One Solution Cell Proliferation assay (MTS; Promega) according to the manufacturer's instructions. Optical density (OD) at $490 \mathrm{~nm}$ was measured on a microplate reader (BioTek Instruments, Inc., Winooski, VT, USA).

RNA extraction and first strand cDNA synthesis. AllPrep DNA/RNA Mini kits (Qiagen, Valencia, CA, USA) were used to extract total RNA from HepG2 cells according to the manufacturer's instructions. Subsequently, a DNA-free ${ }^{\mathrm{TM}}$ kit (Applied Biosystems, Carlsbad, CA, USA) was used to remove genomic DNA. To verify the RNA integrity electrophoresis with 5\% agarose/formaldehyde/MOPS gels was performed, followed by ethidium bromide staining and visual inspection under UV light. Samples with a 28S:18S rRNA ratio less than 2:1 were excluded. A Nanodrop ND-2000 spectrophotometer (Thermo Fisher Scientific Inc., Waltham, MA, USA) was used to measure the RNA concentration. RNA purity was

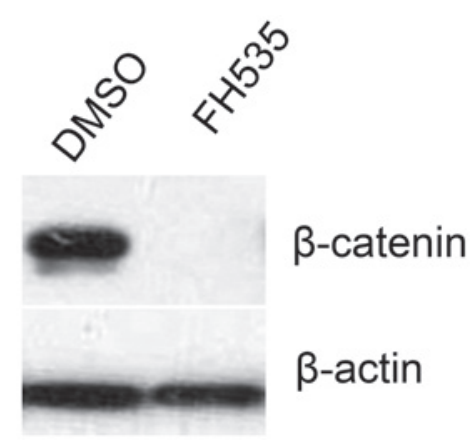

Figure 1. Western blot showing that FH535 inhibits expression of $\beta$-catenin, with $\beta$-actin used as the loading control.

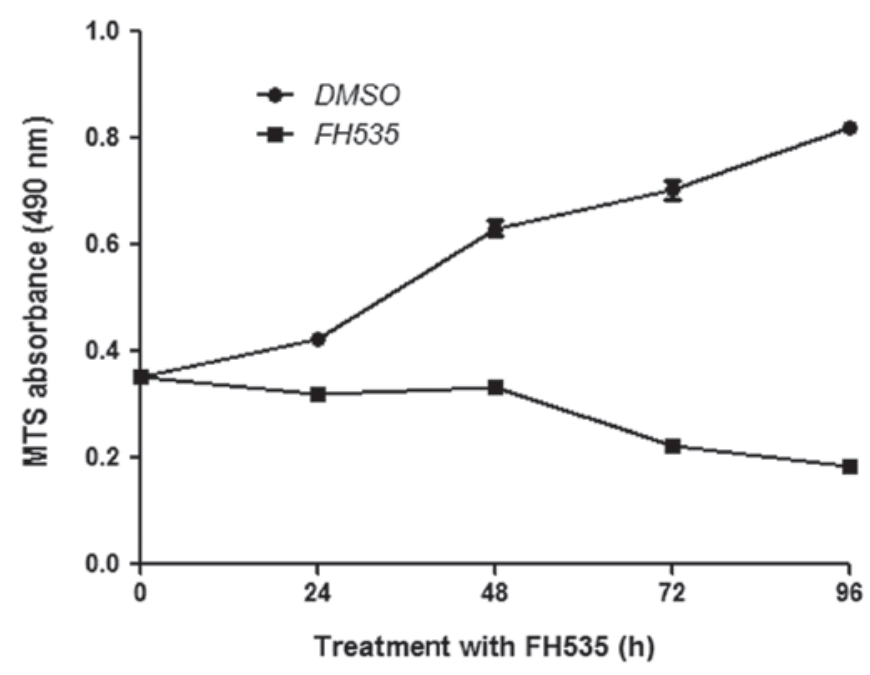

Figure 2. FH535 inhibits proliferation of HepG2 cells.

investigated by calculating the ratio of absorbance at 260 vs. $280 \mathrm{~nm}$, with a ratio of 22.0 as the criterion for 'pure' RNA. Similar results for the quality and integrity of RNA were observed between the HCC and non-cancerous liver tissue samples. First strand cDNA was synthesized from $1 \mu \mathrm{g}$ total RNA, using a High Capacity RNA-to-cDNA kit (Applied Biosystems) according to the manufacturer's instructions. The following conditions were as follows: $37^{\circ} \mathrm{C}$ for $60 \mathrm{~min}$ and $95^{\circ} \mathrm{C}$ for $5 \mathrm{~min}$. First strand cDNA was stored at $-20^{\circ} \mathrm{C}$ until further analysis.

Quantitative real-time polymerase chain reaction ( $q P C R)$. qPCR was used to determine the relative levels of iNOS mRNA in FH535-treated and control HepG2 cells, with $\beta$-actin used as an internal loading control. An ABI StepOne Plus Real-Time PCR System (Applied Biosystems) was used to perform the qPCR, with the following primers: iNOS, forward, 5'-TCC AAG GTA TCC TGG AGC GA-3' and reverse, 5'-CAG GGA CGG GAA CTC CTC TA-3'; $\beta$-actin, forward, 5'-GGA CTT CGA GCA AGA GAT GG-3' and reverse, 5'-AGC ACT GTG TTG GCG TAC AG-3'. All samples were run in triplicate. qPCR amplification was conducted using ABI Power SYBR ${ }^{\circledR}$ Green PCR Master Mix (Applied Biosystems) in $20 \mu \mathrm{l}$ reaction buffer under the 

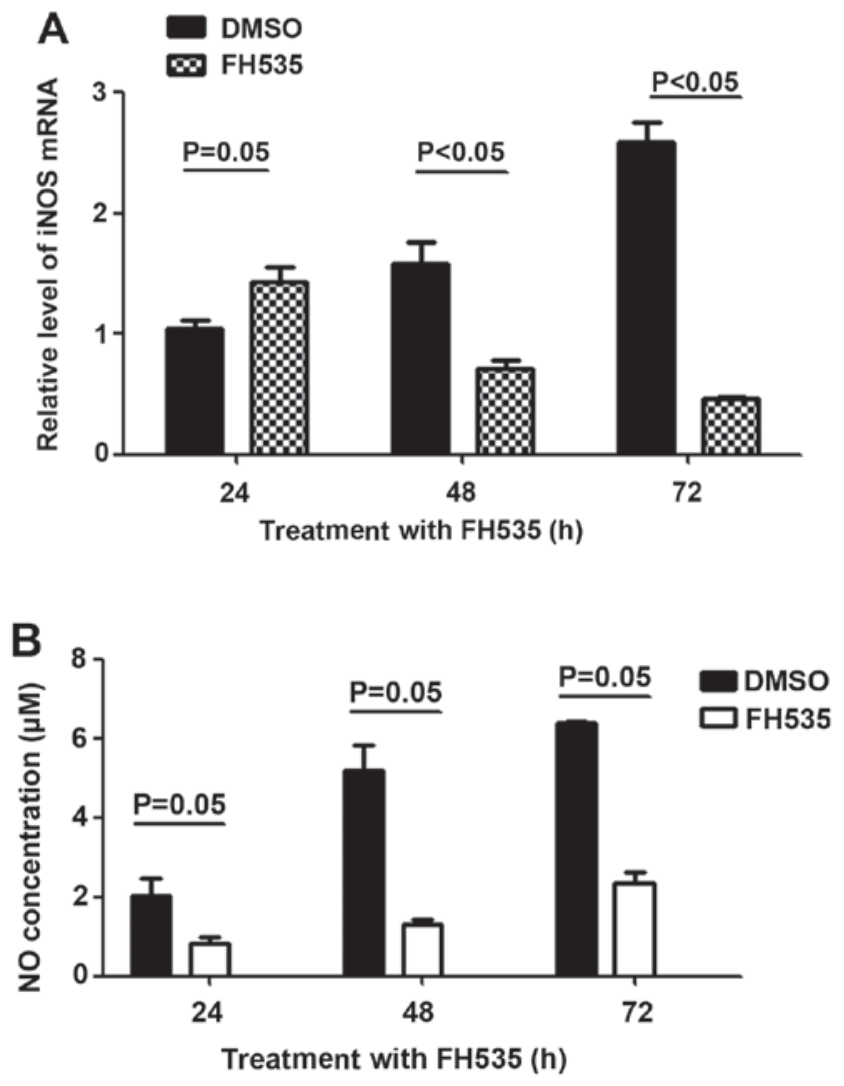

Figure 3. FH535 downregulated the expression of nitric oxide synthase and reduced the production of nitric oxide (NO). (A) FH535 reduced the mRNA level of the nitric oxide synthase gene (iNOS). (B) NO production was inhibited following FH535 treatment.

following conditions: $95^{\circ} \mathrm{C}$ for $10 \mathrm{~min}, 40$ cycles at $95^{\circ} \mathrm{C}$ for $15 \mathrm{sec}$, and $60^{\circ} \mathrm{C}$ for $1 \mathrm{~min}$. Melting curves were analyzed for each sample. Separation of the amplification products was performed by electrophoresis on $2 \%$ agarose gels and they were visualized by ethidium bromide staining. The expected size of iNOS is $317 \mathrm{bp}$. The threshold cycle $(\mathrm{Ct})$ was measured in the exponential amplification phase and amplification plots were analyzed with StepOne v2.2 Software (Applied Biosystems). Similar $\mathrm{Ct}$ values of $\beta$-actin were observed across FH535-treated and control HepG2 cells. The results were normalized against $\beta$-actin and expressed as $2^{-\Delta \Delta C t}$.

Griess assay. HepG2 cells were collected and suspended in minimum essential medium (MEM) at a density of 3,000 cells/100 $\mu \mathrm{l}$. The cell suspensions $(100 \mu \mathrm{l})$ were seeded in 96-well plates, and $4 \mathrm{~h}$ after the cells had attached to the bottom of the wells, the culture medium was replaced with MEM containing $15 \mu \mathrm{M}$ FH535 or DMSO; each assay was performed in triplicate. After incubating for $48 \mathrm{~h}$, the supernatants were collected and nitrite, which is the stable end-product of NO oxidation, was measured using the Griess reagent system (Promega) as per the manufacturer's instructions.

Statistical analysis. Statistical significance was determined by the independent samples t-test using the SPSS software (version 10.0; SPSS, Chicago, IL, USA). P $<0.05$ was considered to indicate statistically significant differences.

\section{Results}

FH535 inhibits the expression of $\beta$-catenin. The effect of FH535 on the expression of $\beta$-catenin was examined. FH535 treatment abolished the protein expression of $\beta$-catenin (Fig. 1). $\beta$-catenin was expressed in the control (DMSO-treated) group.

FH535 inhibits the proliferation of HepG2 cells. Basal expression of $\beta$-catenin is important for cell proliferation. We thus determined the effect of FH535 on the proliferation of HepG2 cells. FH535 reduced HepG2 cell proliferation rates, as assessed by the MTS assay (Fig. 2).

NO concentration is reduced following FH535 treatment. Activation of $\beta$-catenin can upregulate iNOs, and thereby increase the NO concentration. We therefore detected the mRNA expression level of $i N O S$ by reverse transcription polymerase chain reaction (RT-PCR). The results showed that the mRNA of $i N O S$ is decreased following treatment with the $\beta$-catenin inhibitor FH535 (Fig. 3A). The Griess assay also showed that the concentration of NO in FH535-treated HepG2 cells is also reduced compared to the control group (Fig. 3B).

\section{Discussion}

HCC is one of the most frequent and malignant diseases worldwide $(7,15)$. Surgical resection is the treatment of choice at the early stages of HCC (6). However, most HCC patients are in an advanced stage of the disease when diagnosed, and thus do not meet the criteria for surgical treatment. This is one of the reasons for the 5-year survival rate being poor for HCC patients $(2,16)$. The pathophysiology of HCC is not clearly understood, but prognosis of $\mathrm{HCC}$ requires understanding of the underlying molecular mechanism. Hepatocarcinogenesis is a complex process associated with accumulation of genetic and epigenetic changes that occur during initiation, promotion, and progression of the disease (17). These cellular events are often accompanied by increased expression of a number of factors that influence the survival of cancer cells by suppressing apoptosis and regulating the cell cycle. Activation of oncogenes and the role of tumor suppressor genes such as the retinoblastoma and p53 genes, have also been well documented (18). The increasing incidence of HCC has led to intense research aiming to elucidate the physiological, cellular and molecular mechanisms of the disease with the ultimate goal of using this knowledge in the development of new treatment strategies.

The Wnt/ $\beta$-catenin signaling pathway is one of the fundamental pathways directing cell proliferation, cell polarity and cell fate determination during embryonic development and tissue homeostasis (8). $\beta$-catenin is a key component of the $\mathrm{Wnt} / \beta$-catenin signaling pathway (19). Signaling is initiated by the secreted Wnt proteins, which bind to a seven-transmembrane domain receptor encoded by the gene FZD7. Activation of the receptor leads to the phosphorylation of the dishevelled protein, which, through its association with axin, prevents glycogen synthase kinase $3 \beta$ (GSK3 $\beta$ ) from phosphorylating the critical substrate, $\beta$-catenin. Unphosphorylated $\beta$-catenin escapes recognition by $\beta$-TRCP and translocates to the nucleus, where it engages transcription factors such as TCF and LEF to activate the transcription of target genes (20). Abnormal 
activation of the $\mathrm{Wnt} / \beta$-catenin pathway was reported in pancreatic, lung and gastric cancer (21-24).

In addition, the role of the $\mathrm{Wnt} / \beta$-catenin pathway in liver biology is becoming increasingly evident. The Wnt/ $\beta$-catenin pathway is an important player in the progression of $\mathrm{HCC}(9,25)$ Twenty to $90 \%$ of HCCs exhibit $\beta$-catenin activation, induced by diverse mechanisms, including mutations in the gene coding for $\beta$-catenin. Thus, inhibiting the $\mathrm{Wnt} / \beta$-catenin pathway may constitute a target therapy for HCC (26). In this study, our results showed that the $\beta$-catenin inhibitor can reduce proliferation of the HCC cell line HepG2 via downregulation of $\beta$-catenin, and consequently, of its target gene iNOS.

In conclusion, our study has shown that inhibiting the Wnt/ $\beta$-catenin pathway may reduce the proliferation of an HCC cell line and suggested that the Wnt/ $\beta$-catenin pathway constitutes a therapeutic target for treatment of HCC.

\section{References}

1. Siegel R, Naishadham D and Jemal A: Cancer statistics, 2013. CA Cancer J Clin 63: 11-30, 2013.

2. Jemal A, Bray F, Center MM, Ferlay J, Ward E and Forman D: Global cancer statistics. CA Cancer J Clin 61: 69-90, 2011.

3. Yang Z, Miao R, Li G, Wu Y, Robson SC, Yang X, Zhao Y, Zhao $\mathrm{H}$ and Zhong Y: Identification of recurrence related microRNAs in hepatocellular carcinoma after surgical resection. Int J Mol Sci 14: 1105-1118, 2013.

4. Bruix J and Sherman M: Management of hepatocellular carcinoma: an update. Hepatology 53: 1020-1022, 2011.

5. Wertheim JA, Petrowsky H, Saab S, Kupiec-Weglinski JW and Busuttil RW: Major challenges limiting liver transplantation in the United States. Am J Transplant 11: 1773-1784, 2011.

6. El-Serag HB, Marrero JA, Rudolph L and Reddy KR: Diagnosis and treatment of hepatocellular carcinoma. Gastroenterology 134: $1752-1763,2008$

7. Yeh JJ and Uemura M: Hepatocellular carcinoma. N Engl J Med 366: 92; author reply 92-93, 2012.

8. MacDonald BT, Tamai K and He X: Wnt/ $\beta$-catenin signaling: components, mechanisms, and diseases. Dev Cell 17: 9-26, 2009

9. Thompson MD and Monga SP: WNT/ $\beta$-catenin signaling in liver health and disease. Hepatology 45: 1298-1305, 2007.

10. Clevers $H:$ Wnt/ $\beta$-catenin signaling in development and disease. Cell 127: 469-480, 2006.

11. Burke ZD and Tosh D: The Wnt/ $/$-catenin pathway: master regulator of liver zonation? Bioessays 28: 1072-1077, 2006.
12. Siuta M, Zuckerman SL and Mocco J: Nitric oxide in cerebral vasospasm: theories, measurement, and treatment. Neurol Res Int 2013: 972417, 2013.

13. Ozel RE, Alkasir RS, Ray K, Wallace KN and Andreescu S: Comparative evaluation of intestinal nitric oxide in embryonic zebrafish exposed to metal oxide nanoparticles. Small 9: 4250-4261, 2013

14. Du Q, Zhang X, Cardinal J, Cao Z, Guo Z, Shao L and Geller DA: Wnt/beta-catenin signaling regulates cytokine-induced human inducible nitric oxide synthase expression by inhibiting nuclear factor-kappaB activation in cancer cells. Cancer Res 69: 3764-3771, 2009.

15. Bosch FX, Ribes J, Diaz M and Cléries R: Primary liver cancer: worldwide incidence and trends. Gastroenterology 127 (Suppl 1): S5-S16, 2004.

16. Hora C, Romanque P and Dufour JF: Effect of sorafenib on murine liver regeneration. Hepatology 53: 577-586, 2011.

17. Pitot HC: Adventures in hepatocarcinogenesis. Annu Rev Pathol 2: 1-29, 2007

18. Hussain SP, Schwank J, Staib F, Wang XW and Harris CC: TP53 mutations and hepatocellular carcinoma: insights into the etiology and pathogenesis of liver cancer. Oncogene 26: 2166-2176, 2007.

19. Willert K and Jones KA: Wnt signaling: is the party in the nucleus? Genes Dev 20: 1394-1404, 2006.

20. Gordon MD and Nusse R: Wnt signaling: multiple pathways, multiple receptors, and multiple transcription factors. J Biol Chem 281: 22429-22433, 2006.

21. Thu KL, Radulovich N, Becker-Santos DD, Pikor LA, Pusic A, Lockwood WW, Lam WL and Tsao MS: SOX15 is a candidate tumor suppressor in pancreatic cancer with a potential role in Wnt $/ \beta$-catenin signaling. Oncogene: Jan 14, 2013 (Epub ahead of print). doi: $10.1038 /$ onc.2012.595.

22. Clements WM, Wang J, Sarnaik A, Kim OJ, MacDonald J, Fenoglio-Preiser C, Groden J and Lowy AM: $\beta$-Catenin mutation is a frequent cause of Wnt pathway activation in gastric cancer. Cancer Res 62: 3503-3506, 2002.

23. Li H, Mo J, Jia G, Liu C, Luan Z and Guan Y: Activation of Wnt signaling inhibits the pro-apoptotic role of Notch in gastric cancer cells. Mol Med Rep 7: 1751-1756, 2013.

24. Shapiro M, Akiri G, Chin C, Wisnivesky JP, Beasley MB, Weiser TS, Swanson SJ and Aaronson SA: Wnt pathway activation predicts increased risk of tumor recurrence in patients with stage I nonsmall cell lung cancer. Ann Surg 257: 548-554, 2013.

25. Lustig B and Behrens J: The Wnt signaling pathway and its role in tumor development. J Cancer Res Clin Oncol 129: 199-221, 2003.

26. Luo X, Li HX, Liu RX, Wu ZS, Yang YJ and Yang GS: $\beta$-catenin protein utilized by Tumour necrosis factor-alpha in porcine preadipocytes to suppress differentiation. BMB Rep 42: 338-343, 2009. 